\title{
A preliminary phylogeny of Zapoteca (Fabaceae: Caesalpinioideae: Mimosoid clade)
}

\author{
Julia Ferm ${ }^{1} \mathbb{B}$
}

Received: 27 October 2018 / Accepted: 20 March 2019 / Published online: 5 April 2019

(c) The Author(s) 2019

\begin{abstract}
The legume genus Zapoteca is separated from the genus Calliandra, i.e., by having pollen arranged in 16-grained polyads (compared to 8-grained polyads in Calliandra) and in chromosome number (13 vs. 8 or 11). As currently circumscribed, Zapoteca contains 22 species and 13 subspecies placed in five subgenera. This study included 20 species and 11 subspecies representing all subgenera. Representative species from the closely related genera Calliandra, Havardia, Pithecellobium and Viguieranthus were also included, as the more distantly related species Senegalia senegal and Vachellia farnesiana. The aims of this study were to test the monophyly of Zapoteca and investigate phylogenetic relationships within the genus. Total DNA was extracted from leaf material and the nuclear ETS and ITS, and plastid $t r n \mathrm{~L}-t r n \mathrm{~F}$ regions were amplified. Additional sequence data were downloaded from GenBank, and the data sets were analyzed using Bayesian inference. Results show that Zapoteca is monophyletic and that the monospecific subgenera (subg. Nervosa and subg. Aculeata) are resolved as separate lineages within the genus, subg. Nervosa (containing Z. nervosa) as sister to all remaining taxa of Zapoteca. Subgenera containing more than one species (subg. Amazonica, subg. Zapoteca and subg. Ravenia) are shown to be nonmonophyletic. Two subspecies of $Z$. caracasana, subsp. caracasana and subsp. weberbaueri, are found together in a clade. Furthermore, Zapoteca tehuana and Z. portoricensis subsp. portoricensis, Z. formosa subsp. gracilis and Z. formosa subsp. schottii are shown to be monophyletic. However, the other subspecific taxa of Z. formosa and of Z. portoricensis are not supported as monophyletic.
\end{abstract}

Keywords Bayesian inference $\cdot$ Leguminosae $\cdot$ Neotropics $\cdot$ Phylogenetic analyses $\cdot$ Taxonomy

\section{Introduction}

The mimosoid genus Zapoteca H.M.Hern. (Fabaceae) mostly comprises erect or scandent shrubs up to 3-4 m tall with the main woody stems $1-2 \mathrm{~cm}$ in diameter, although individuals of $Z$. tetragona (Willd.) H.M.Hern. and Z. portoricensis (Jacq.) H.M.Hern. are reported to have stems up to $20 \mathrm{~cm}$ in diameter (Hernández 1989). Zapoteca is further characterized by stipulate, bipinnate leaves with opposite leaflets that range from $0.5 \mathrm{~cm}(Z$. alinae H.M.Hern. and Z. media (M.Martens \& Galeotti) H.M.Hern.) to $22 \mathrm{~cm}$ (Z. amazonica (Benth.) H.M.Hern.) in length, the number of

Handling Editor: Louis P. Ronse De Craene.

Julia Ferm

julia.ferm@ebc.uu.se

1 Department of Organismal Biology, Systematic Biology, Uppsala University, Norbyv. 18D, 75236 Uppsala, Sweden leaflets on each leaf being inversely related to leaflet size (Hernández 1989). The members of Zapoteca have axillary inflorescences with densely assembled flowers, each with ca. 30-60 stamens with long-exserted, white, pink, purple or bicolored filaments. The pods are dry and straight with thickened margins, the valves dehiscing explosively from the apex to the base. The seeds are hard and arranged in one series (Hernández 1989).

Zapoteca has its highest species diversity in southern Mexico but has a total distribution ranging from southwestern USA to northern Argentina, including the West Indies. They can be found from sea level up to ca. $2850 \mathrm{~m}$ altitude (Tropicos.org 2018). Most species grow in tropical dry forest and disturbed habitats in seasonally dry areas, but some species occur in montane wet forest and lowland rainforest (Hernández 1989).

Zapoteca was described by Hernández (1986). He considered the members of Calliandra ser. Laetevirentes Benth. to be morphologically different from all other 
species of Calliandra Benth. and described Zapoteca to accommodate the approximately 25 species of this series. However, he only provided new combinations in Zapoteca for seven of them. The newly recognized genus Zapoteca was characterized by having pollen arranged in 16-grained polyads, thin and membranous (rarely coriaceous) leaflets and membranous to coriaceous pods, whereas the genus Calliandra has pollen in 8-grained polyads, chartaceous to coriaceous leaflets and rigid pods. Also, the basic chromosome number of Zapoteca is 13 (shared with the other members of Ingeae), while in Calliandra the basic chromosome number is 8 or 11 (Hernández 1986).

Hernández (1986) also discussed the possibility that two species of Calliandra ser. Macrophyllae Benth., $C$. amazonica Benth. and C. aculeata Spruce ex Benth., were misplaced in Calliandra, but was uncertain if they should be placed in Zapoteca. He pointed out that these two species and Zapoteca share the same polyad and inflorescence structures, but that the small number and larger size of the leaflets distinguishes them from all other species of Zapoteca. Therefore, Hernández (1986) considered further studies needed before any change in their taxonomic content or placement should be formally proposed.

A few years later Hernández (1989) presented a monograph of Zapoteca and provided new combinations in the genus for the remaining species of Calliandra ser. Laetevirentes, as well as those of ser. Macrophyllae mentioned above. By doing this, Hernández (1989) expanded Zapoteca to contain a total of 17 species and 11 subspecies (Table 1). Furthermore, in that work he recognized four subgenera, viz. subg. Nervosa H.M.Hern., subg. Zapoteca, subg. Aculeata H.M.Hern. and subg. Amazonica H.M.Hern. (Table 1), based on variation in vegetative characters such as leaf morphology and venation patterns of the leaflets. Following this classification, subg. Zapoteca has a distribution from Mexico throughout the Neotropics, while subg. Aculeata and subg. Amazonica are restricted to South America and subg. Nervosa to the West Indies.

Since the work by Hernández (1989) one additional subgenus, subg. Ravenia H.M.Hern., as well as five species and one subspecies have been described (Hernández 1990, 2015; Hernández and Campos 1994; Hernández and Hanan-Alipi 1998) (Table 1). Furthermore, one additional species of Calliandra, C. socorrensis I.M.Johnst., has been transferred to Zapoteca and placed as a subspecies of $Z$. formosa (Kunth) H.M.Hern. (Levin and Moran 1989). Thus, at present, Zapoteca consists of 21 species in five subgenera, with Z. formosa, Z. caracasana (Jacq.) H.M.Hern. and $Z$. portoricensis divided into eight, two and three subspecies, respectively (Table 1). Zapoteca sousae H.M.Hern. \& A.Campos has not yet been placed in any subgenus although Hernández and Campos (1994) emphasized the resemblance of this species to Z. portoricensis subsp. portoricensis, indication of a placement in subg. Zapoteca.

Previous phylogenetic studies of mimosoid legumes (Brown et al. 2008; Souza et al. 2013; Ferm et al. in prep.) have shown Zapoteca to be monophyletic. However, these studies included only a limited number of species of Zapoteca. DNA regions used in these studies were ETS and ITS (Brown et al. 2008), ITS and trnL-trnF (Souza et al. 2013), and ETS, ITS, $p s b A-t r n H$ and $t r n \mathrm{~L}-t r n \mathrm{~F}$ (Ferm et al. in prep.). Therefore, an analysis including a higher number of sampled species and subspecies of Zapoteca was considered necessary in order to thoroughly investigate the monophyly of Zapoteca, and currently recognized subgenera, as well as other phylogenetic relationships within the genus.

In this study, I present a phylogenetic analysis of Zapoteca, based on nuclear and plastid DNA sequence data, as a first step in investigating the evolutionary history of the genus. I sampled from all subgenera of Zapoteca and also included eight species from other genera closely related to Zapoteca (Souza et al. 2013; Ferm et al. in prep.), as well as the more distantly related, mimosoid species Senegalia senegal (L.) Britton and Vachellia farnesiana (L.) Wight \& Arn. The study was carried out in order to (1) test the monophyly of Zapoteca; (2) test the monophyly of the subgenera in Zapoteca; and (3) evaluate phylogenetic relationships within Zapoteca.

\section{Materials and methods}

\section{Taxon and DNA region sampling}

This study is based on DNA sequence data from 20 species and 11 subspecies of Zapoteca (Table 1), representing all presently recognized subgenera (Hernández 1989, 1990). In order to test the monophyly of the genus, eight species from genera previously shown to be closely related to Zapoteca (Souza et al. 2013; Ferm et al. in prep.) were included in the analyses. In addition, Senegalia senegal and Vachellia farnesiana were included to represent more distantly related species (Kyalangalilwa et al. 2013). When available, several specimens of the same taxon were included in order to test the coherence of species and subspecies of Zapoteca as currently circumscribed (Hernández 1986, 1989, 1990, 2015; Levin and Moran 1989; Hernández and Campos 1994; Hernández and Hanan-Alipi 1998). Newly generated DNA sequences and previously published DNA sequence data (downloaded from GenBank) from a total of 58 specimens were included in the analyses. Voucher information and GenBank accession numbers are listed in Appendix.

The amplified DNA regions comprise the nuclear external transcribed spacer (ETS), the nuclear internal transcribed spacer (ITS) and the plastid region trn $\mathrm{L}-t r n \mathrm{~F}$ 
Table 1 Subgenera, species and subspecies of Zapoteca according to Hernandez (1989, 1990, 2015), Levin and Moran (1989), Hernández and Campos (1994) and Hernández and Hanan-Alipi (1998)

\begin{tabular}{|c|c|c|}
\hline Subgenus & Species & Subspecies \\
\hline Acuelata H.M.Hern. ${ }^{\mathrm{b}}$ & Zapoteca aculeata (Spruce ex Benth.) H.M.Hern. ${ }^{\text {b }}$ & - \\
\hline \multirow[t]{3}{*}{ Amazonica H.M.Hern. ${ }^{\text {b }}$} & Zapoteca amazonica (Benth.) H.M.Hern. ${ }^{\text {b }}$ & - \\
\hline & Zapoteca microcephala (Britton \& Killip) H.M.Hern. ${ }^{\text {b }}$ & - \\
\hline & Zapoteca quichoi H.M.Hern. \& A.M.Hanan ${ }^{\mathrm{f}}$ & - \\
\hline Nervosa H.M.Hern. ${ }^{\text {b }}$ & Zapoteca nervosa (Urb.) H.M.Hern. ${ }^{\text {b }}$ & - \\
\hline \multirow[t]{2}{*}{ Ravenia H.M.Hern. ${ }^{\mathrm{d}}$} & Zapoteca ravenii H.M.Hern. ${ }^{\mathrm{d}}$ & - \\
\hline & Zapoteca tehuana H.M.Hern. ${ }^{\text {b }}$ & - \\
\hline \multirow[t]{24}{*}{ Zapoteca H.M.Hern. ${ }^{\mathrm{b}}$} & Zapoteca alinae H.M.Hern. ${ }^{\text {b }}$ & - \\
\hline & Zapoteca andina H.M.Hern. ${ }^{\mathrm{b}}$ & - \\
\hline & Zapoteca balsasensis H.M.Hern. ${ }^{\mathrm{g}}$ & - \\
\hline & Zapoteca caracasana (Jacq.) H.M.Hern. ${ }^{\text {a }}$ & caracasana $^{\mathrm{b}}$ \\
\hline & & weberbaueri (Harms) H.M.Hern. ${ }^{b}$ \\
\hline & Zapoteca costaricensis (Britton \& Rose) H.M.Hern. ${ }^{\text {b }}$ & - \\
\hline & Zapoteca cruzii H.M.Hern. ${ }^{\mathrm{g}}$ & - \\
\hline & Zapoteca filipes (Benth.) H.M.Hern. ${ }^{b}$ & - \\
\hline & Zapoteca formosa (Kunth) H.M.Hern. ${ }^{\text {a }}$ & formosa $a^{\mathrm{b}}$ \\
\hline & & gracilis (Griseb.) H.M.Hern. ${ }^{\text {b }}$ \\
\hline & & mollicula (J.F.Macbr.) H.M.Hern. ${ }^{\text {b }}$ \\
\hline & & rosei (Wiggins) H.M.Hern. ${ }^{\text {b }}$ \\
\hline & & salvadorensis (Britton \& Rose) H.M.Hern. ${ }^{\text {b }}$ \\
\hline & & schottii (Torr. ex S. Watson) H.M.Hern. ${ }^{\text {b }}$ \\
\hline & & sinaloana H.M.Hern. ${ }^{\mathrm{g}}$ \\
\hline & & $\begin{array}{l}\text { socorrensis (I.M.Johnst.) G.A.Levin, } \\
\text { H.M.Hern. \& Moran }{ }^{c}\end{array}$ \\
\hline & Zapoteca lambertiana (G.Don) H.M.Hern. ${ }^{\text {a }}$ & - \\
\hline & Zapoteca media (M.Martens \& Galeotti) H.M.Hern. ${ }^{a}$ & - \\
\hline & Zapoteca mollis (Stand1.) H.M.Hern. ${ }^{a}$ & - \\
\hline & Zapoteca portoricensis (Jacq.) H.M.Hern. ${ }^{\text {a }}$ & flavida (Urb.) H.M.Hern. ${ }^{\mathrm{b}}$ \\
\hline & & portoricensis ${ }^{\mathrm{b}}$ \\
\hline & & pubicarpa H.M.Hern. ${ }^{\mathrm{b}}$ \\
\hline & Zapoteca scutellifera (Benth.) H.M.Hern. ${ }^{\text {b }}$ & - \\
\hline & Zapoteca tetragona (Willd.) H.M.Hern. ${ }^{\text {b }}$ & - \\
\hline Not specified & Zapoteca sousae H.M.Hern. \& A.Campos ${ }^{\mathrm{e}}$ & - \\
\hline
\end{tabular}

Species and subspecies included in this study are given in bold type

${ }^{a}$ Hernández (1986); ${ }^{b}$ Hernández (1989); ${ }^{c}$ Levin and Moran (1989); ${ }^{d}$ Hernández (1990); ${ }^{e}$ Hernández and Campos (1994); ${ }^{\mathrm{f}}$ Hernández and HananAlipi (1998); ${ }^{\mathrm{g}}$ Hernández (2015)

(including the $\operatorname{trn} \mathrm{L}$ intron and the $\operatorname{trn} \mathrm{L}-\operatorname{trn} \mathrm{F}$ spacer). These regions have previously been used in phylogenetic studies of genera closely related to Zapoteca (including also species of Zapoteca) where they show a high number of variable sites (Brown et al. 2008; Souza et al. 2013; Ferm et al. in prep.).

\section{DNA extraction, amplification and sequencing}

Total DNA was extracted from leaf material obtained from the herbaria at New York Botanical Garden (NY), the
Swedish Museum of Natural History (S), Missouri Botanical Garden (MO) and the National Herbarium of Mexico (MEXU) following the protocol listed in Ferm et al. (in prep.). One additional DNA sample was obtained from Centro de Investigación Cientifica de Yucatán (CICY).

PCRs included $1.5 \mu \mathrm{l} 10 \times$ Dream taq buffer with $20 \mu \mathrm{M}$

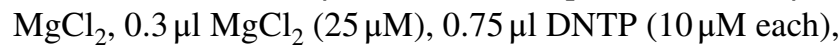
$0.15 \mu \mathrm{l}$ of each primer $(20 \mu \mathrm{M}), 0.15 \mu \mathrm{l} \mathrm{BSA} 1 \%$, and $0.075 \mu \mathrm{l}$ Dream Taq DNA polymerase $(5 \mathrm{U} / \mu \mathrm{l})$ with $1 \mu \mathrm{l}$ DNA template and $10.925 \mu$ sterilized $\mathrm{H}_{2} \mathrm{O}$ giving a total volume of $15 \mu \mathrm{l}$. ETS was amplified using the primers AcR2 (Ariati 
et al. 2006) and 18S IGS (Baldwin and Markos 1998). ITS and $t r n \mathrm{~L}-t r n \mathrm{~F}$ were amplified in two separate reactions. For ITS primers P17 (Popp and Oxelman 2001) with ITS 491 (Ferm et al. in prep.) and ITS 493 (Ferm et al. in prep) with 26S-82R (Popp and Oxelman 2001) were used. For $t r n \mathrm{~L}-t r n \mathrm{~F}$, the universal primers $\mathrm{c}, \mathrm{d}$ and e were used (Taberlet et al. 1991), c with d and e with jf1 (Ferm et al. in prep.). The primers used are listed in Table 2 .

PCRs were run on an Applied Biosystems Veriti ${ }^{\mathrm{TM}}$ 96-Well Thermal Cycler. Amplifications were carried out as follows: 3-min initial denaturation at $95{ }^{\circ} \mathrm{C}$ followed by 35 cycles of 30 -s denaturation at $95{ }^{\circ} \mathrm{C}, 1-\mathrm{min}$ annealing at $55^{\circ} \mathrm{C}$ and 1 -min extension at $72{ }^{\circ} \mathrm{C}$, and completed by a final extension of $7 \mathrm{~min}$ at $72{ }^{\circ} \mathrm{C}$.

The products were purified using Illustra ExoProStar 1-Step (GE Healthcare, Little Chalfont, UK) following the instructions from the manufacturer and sent to Macrogen Europe in Amsterdam, the Netherlands, for sequencing. The same primers were used for sequencing as for PCR (Fig. 1).

\section{Multiple sequence alignment and phylogenetic analyses}

Complementary strands of the sequences were assembled and edited using Geneious v.10.1.2 (https://www.geneious. com, Kearse et al. 2012). For each region, multiple alignments of the sequences were performed using MUSCLE (Edgar 2004), and corrected by eye, in AliView v.1.19beta-3 (Larsson 2014).

Before analysis, the best-fitting nucleotide substitution models for each of the data sets were determined using MrAic v.1.4.6 (Nylander 2004). The GTR-I-G model was selected for ETS and the GTR-G model was selected for ITS and $t r n \mathrm{~L}-t r n \mathrm{~F}$. Bayesian inference analyses were performed for each data set using MrBayes v.3.2.6 (Ronquist et al. 2011). Two parallel MCMC chains were run for 1 million generations with a sampling frequency of 1000 . The average standard deviation of split frequencies was below 0.01 at the end of each of the runs, indicating that the Markov chains had converged on the stationary distribution. Ten percent of the sampled trees were discarded as burn-in after evaluation of the output parameters generated by the Bayesian analysis in Tracer v.1.6 (Rambaut et al. 2014). Majority-rule 50\% consensus trees were calculated based on the remaining trees and inspected in FigTree v.1.4.3 (Rambaut 2006).

The trees were rooted using Vachellia farnesiana, a species phylogenetically distant from the members of Zapoteca (Kyalangalilwa et al. 2013). I consider nodes with a posterior probability (PP) of $\geq 0.95$ as strongly supported. The resulting topologies from each of the single-region data sets were compared manually to detect potential conflicting topologies. No incongruences were discovered and the data sets of the individual regions were therefore concatenated using Abioscripts (Larsson 2010). The combined data set was analyzed using the same methods and settings as the single-region data sets. Newly obtained sequences were deposited in GenBank (Appendix). The aligned data sets and the phylogenetic trees are available in TreeBase (http://purl.org/phylo/treebase/phylo ws/study/TB2:S23432).

\section{Results}

\section{Characteristics of each DNA sequence region are summarized in Table 3}

The results of the three separate analyses of the singleregion data sets show that Zapoteca is strongly supported as monophyletic (PP 1 in all analyses) and that $Z$. nervosa
Table 2 Primers used in this study

\begin{tabular}{llll}
\hline DNA region & Primer & Sequence 5'-3' & Reference \\
\hline $\begin{array}{l}\text { Forward } \\
\text { ETS }\end{array}$ & AcR2 & GGG CGT GTG AGT GGT GTT TGG & Ariati et al. (2006) \\
ITS (part 1) & P17 & CTA CCG ATT GAA TGG TCC GGT GAA & Popp and Oxelman (2001) \\
ITS (part 2) & ITS 493 & ATG CGA TAC TTG GTG TGA AT & Ferm et al. (in prep) \\
trnL-trnF & $\mathrm{c}$ & CGC GCA TGG TGG ATT CAC AAA TC & Taberlet et al. (1991) \\
trnL-trnF & $\mathrm{e}$ & GGT TCA AGT CCC TCT ATC CC & Taberlet et al. (1991) \\
$\begin{array}{l}\text { Reverse } \\
\text { ETS }\end{array}$ & & & \\
ITS (part 1) & ITS 491 & TCA CAC CAA GTA TCG CAT TT & Ferm et al. (in prep.) \\
ITS (part 2) & 26S-82R & TCC CGG TTC GCT CGC CGT TAC & Popp and Oxelman (2001) \\
trnL-trnF (part 1) & $\mathrm{d}$ & GGG ATA GAG GGA CTT GAA CC & Taberlet et al. (1991) \\
trnL-trnF (part 2) & Jf1 & ATT TGA ACT GGT GAC ACG AGG & Ferm et al. (in prep.) \\
\hline
\end{tabular}


Fig. 1 a-c Three species of Zapoteca showing inflorescences and bipinnate leaves. a Zapoteca portoricensis subsp. portoricensis. Photo: S.M. Silvestrini. b Zapoteca formosa subsp. gracilis. Photo: P.G. Gutiérrez. c Zapoteca caracasana. Photo: G. Lewis
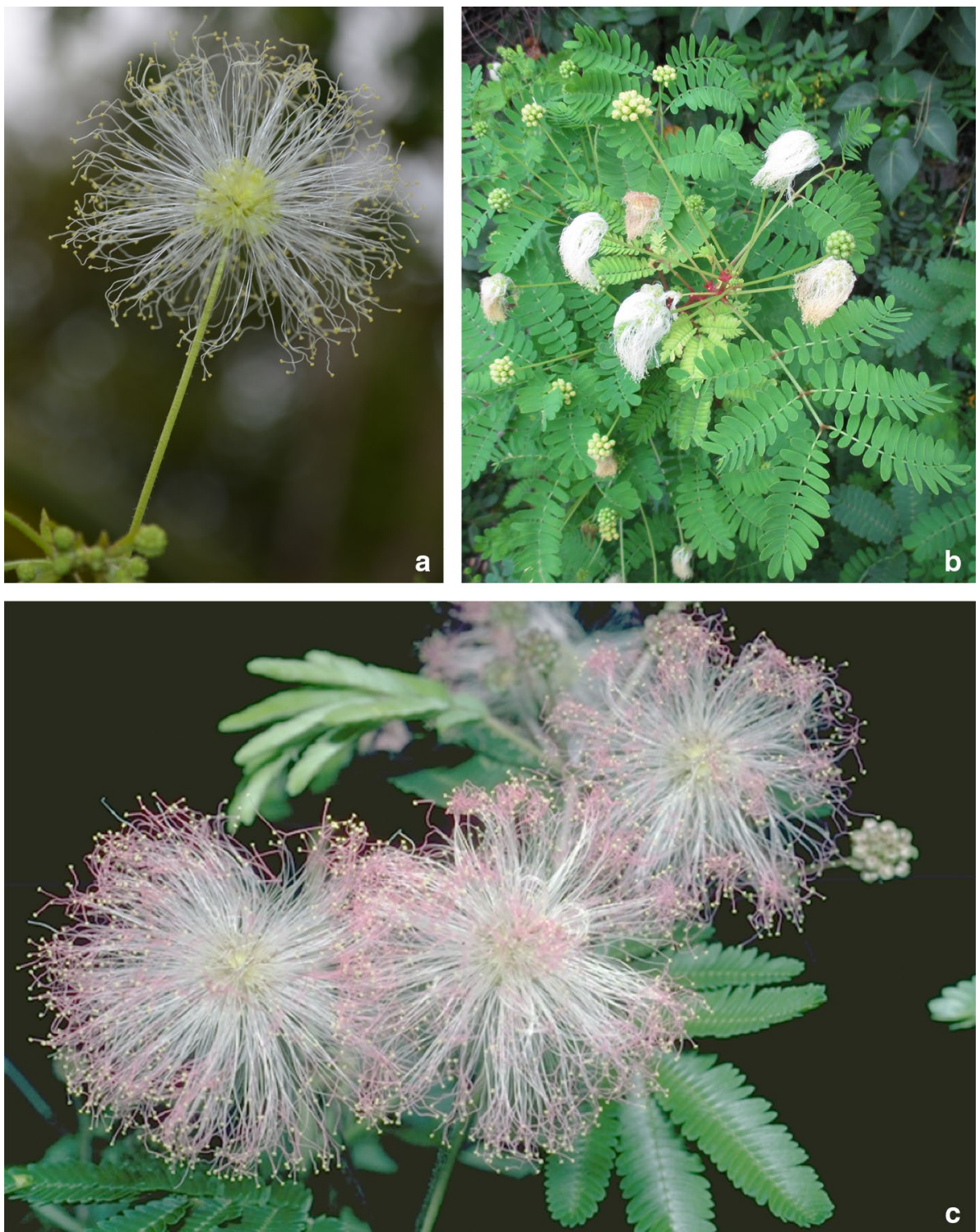

(Urb.) H.M.Hern. is the sister to the remaining species in the genus (supported by PP 1 for ETS; PP 1/PP 0.99 for ITS; PP 1 for $t r n \mathrm{~L}-t r n \mathrm{~F}$ for the two nodes involved). Trees from the separate analyses are available in Treebase (http://purl.org/phylo/treebase/phylows/study/TB2:S2343 2).

The 50\% majority-rule consensus tree derived from the Bayesian analysis of the combined data set (ETS, ITS and $\operatorname{trn} \mathrm{L}-t r n \mathrm{~F})$ is presented in Fig. 2. The results show that Zapoteca is monophyletic (PP 1). The monospecific subg. Nervosa (Table 1) is sister to all the remaining species of Zapoteca (PP 1). The other monospecific subgenus, subg. Aculeata (Table 1), is also found as a separate lineage (PP 1/PP 0.99). In contrast, none of the subgenera containing more than one species, namely subg. Zapoteca, subg. Amazonica and subg. Ravenia (Table 1), are supported as being monophyletic in this study. Furthermore, many nodes within Zapoteca are strongly supported, but relationships at species and subspecies levels are for the most part not strongly supported.

The results show that the two specimens of Zapoteca nervosa form a clade (PP 1), which is sister to a clade containing the remaining species of Zapoteca (PP 1). Within the latter clade, three monophyletic groups including more than one species or subspecies are found. These are referred to as clades I-III (Fig. 2).

Clade I (PP 1) is sister to a clade consisting of Z. $a c u$ leata (Spruce ex Benth.) H.M.Hern and Z. amazonica, plus clades II and III (PP 1). Clade I includes Zapoteca filipes (Benth.) H.M.Hern. and Z. scutellifera (Benth.) H.M.Hern. However, Zapoteca filipes A is sister to Z. scutellifera (PP 0.89 ), and they are together sister to Zapoteca filipes B (PP 1). 
Table 3 Number of accessions, number of characters, number/ percentage of variable characters and substitution model for data sets analyzed with Bayesian inference

\begin{tabular}{llcll}
\hline Data set & \# Accessions & \# Characters & $\begin{array}{l}\text { Variable charac- } \\
\text { ters \#/(\%) }\end{array}$ & Substitution model \\
\hline ETS & 38 & 467 & $281 /(60 \%)$ & GTRIG \\
ITS & 57 & 863 & $303 /(35 \%)$ & GTR-G \\
trnL-trnF & 41 & 1329 & $223 /(17 \%)$ & GTR-G \\
Combined data set & 60 & 2635 & $812 /(31 \%)$ & - \\
\hline
\end{tabular}

Zapoteca aculeata is monophyletic (PP 1) and sister to the remaining taxa consisting of $Z$. amazonica plus clades II and III (PP 1/PP 0.99). Zapoteca amazonica in turn is sister to clades II and III together (PP 0.99/PP 1).

The results show that clade II and clade III are sisters (PP 1/PP 1). Clade II (PP 1) contains the monophyletic $Z$. caracasana (PP 1) with $Z$. caracasana subspecies weberbaueri shown to be monophyletic (PP 1) and as sister to $Z$. caracasana subsp. caracasana (PP 1).

Most of the taxa of Zapoteca included in this study are found in clade III (PP 1). Here, two well-supported subclades are found, in Fig. 2 marked with X (PP 0.99) and Y (PP 0.99). In subclade X, Zapoteca formosa subsp. gracilis (Griseb.) H.M.Hern. and Z. portoricensis subsp. portoricensis are both monophyletic (PP 1/PP 1) and found as sisters (PP 0.94). However, Zapoteca portoricensis is shown to be non-monophyletic since Z . portoricensis subsp. pubicarpa H.M.Hern. is found in a poorly supported position, excluded from subclade $\mathrm{X}$. The two specimens of $Z$. tetragona are both found in subclade $\mathrm{X}$, but the species is not supported as being monophyletic. Furthermore, Z. quichoi H.M.Hern. \& A.M.Hanan, Z. mollis (Standl.) H.M.Hern., Z. costaricensis (Britton \& Rose) H.M.Hern. and Z. formosa A are found in this subclade, but the phylogenetic relationships between these species and to the other species in subclade $\mathrm{X}$ are not resolved.

In subclade $\mathrm{Y}$, two monophyletic groups are found as sisters (PP 0.99/PP 0.98). One of these groups contains $Z$. formosa subsp. socorrensis (I.M.Johnst.) G.A.Levin et al. and Z. formosa subsp. rosei (Wiggins) H.M.Hern. (PP 1) and the other contains the remaining taxa in subclade $Y$, viz., Z. lambertiana (G.Don) H.M.Hern., Z. media, Z. formosa subsp. schottii (Torr. ex S.Watson) H.M.Hern., Z. formosa subsp. mollicula (J.F.Macbr.) H.M.Hern. and Z. alinae (PP 0.98). Zapoteca formosa subsp. schottii is shown to be monophyletic (PP 1) based on three collections. The three specimens of $Z$. lambertiana included in this work are found in subclade Y, but they are not resolved as being monophyletic nor shown to be non-monophyletic since none of their positions within this clade are supported. Two out of three specimens of $Z$. alinae are found in subclade $Y$, but not as sisters, and one is found outside subclade $\mathrm{Y}$, showing that this species is non-monophyletic.
Zapoteca sousae and Z. formosa B are found outside subclades $\mathrm{X}$ and $\mathrm{Y}$ and shown to be sisters (PP 1), as are $Z$. ravenii H.M.Hern. and Z. cruzii H.M.Hern. (PP 1). Zapoteca tehuana H.M.Hern. is shown to be monophyletic based on two terminals (PP 1), but its position in relation to the other taxa in clade III is unresolved.

Finally, all specimens of $Z$. formosa are found in clade III, but this species is not shown to be monophyletic since subspp. of $Z$. formosa are intermixed with other taxa in clade III. Subspecies Z. formosa subsp. schotti (PP 1) and subsp. gracilis (PP 1) are the only subspecies of $Z$. formosa shown to be monophyletic.

\section{Discussion}

In this study, both the separate analyses of each DNA region (trees not presented) and the combined analysis (ETS, ITS and $t r n \mathrm{~L}-t r n \mathrm{~F}$ ) (Fig. 2) show that Zapoteca is strongly supported as monophyletic. These results are in accordance with previous work based on much fewer taxa (Brown et al. 2008; Souza et al. 2013; Ferm et al. in prep.). The results of the combined analysis (Fig. 2) are discussed below.

\section{Monophyly of subgenera of Zapoteca}

The monospecific subgenera, subg. Nervosa (containing Z. nervosa) and subg. Aculeata (containing Z. aculeata), are recovered as early diverging and distinct lineages within Zapoteca, whereas subg. Amazonica, represented by two species, is shown to be non-monophyletic (Fig. 2). One of the species of subg. Amazonica, Z. amazonica, is found as sister to clades II and III, whereas the other one, Zapoteca quichoi, is found to clade III (Fig. 2). The third, and in this study missing, member of subg. Amazonica, $Z$. microcephala (Britton \& Killip) H.M.Hern., is a rare and seldom collected species (Tropicos.org 2018), but must be included in any future analysis in order to further test the status of subg. Amazonica. Subgenus Ravenia is shown to be non-monophyletic. The two species included in subg. Ravenia, Z. ravenii and Z. tehuana (Hernández 1990), are both found in clade III, but not as sisters (Fig. 2). The species placed in subg. Zapoteca (Hernández, 1989, 2015; Levin and Moran 1989) are found in clades I, II and III, 


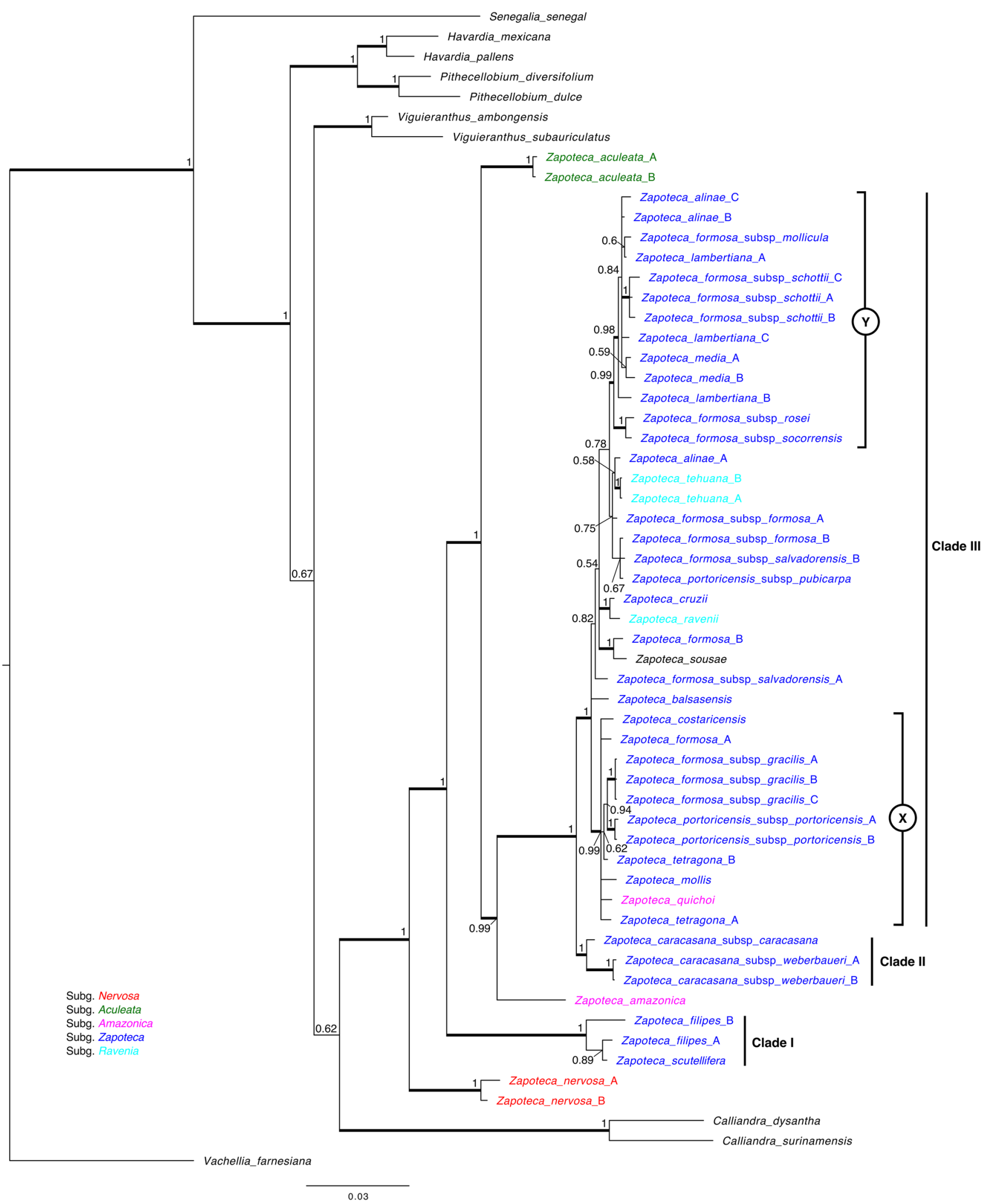

Fig. 2 Majority-rule (50\%) consensus tree of 900 trees sampled at stationarity from the Bayesian analysis of the combined data set (ETS, ITS and trnL-trnF). Clades I-III are indicated with lines, and subclades $\mathrm{Y}$ and $\mathrm{X}$ within clade III are indicated with bracts. Num- bers at nodes represent posterior probabilities, and thick lines indicate strong support $(\mathrm{PP} \geq 95)$. Current subgeneric classification is indicated with colors 
but since species of both subg. Amazonica and subg. Ravenia also are found in clade III, subg. Zapoteca is nonmonophyletic (Fig. 2). As a consequence of the results in this study, a new subgeneric classification for the taxa in subg. Zapoteca, subg. Ravenia and subg. Amazonica is necessary, but further studies of both molecular and morphological data are needed before any taxonomic changes should be formally proposed.

\section{Phylogenetic relationships within Zapoteca}

The results of this study show that Zapoteca nervosa is the strongly supported sister to a group consisting of all the other species of Zapoteca (Fig. 2). This species is endemic to Hispaniola and was placed in subg. Nervosa as its only species by Hernández (1989). Zapoteca nervosa is distinguished from the other species of Zapoteca in having fissured bark and large, gray, coriaceous leaflets with a venation pattern not seen in any other member of the genus. Hernández (1989) suggested that $Z$. nervosa had diverged early from the other members of Zapoteca particularly evidenced by the absence of a lens-shaped structure in the central cells of the 16-celled pollen polyads (present in all other members of Zapoteca) (Guinet and Hernández 1989). The position of $Z$. nervosa as sister to all remaining species of Zapoteca, as shown in this study (Fig. 2), supports this idea of a long separate history of this species and seemingly merits the placement of $Z$. nervosa in a separate subgenus (Hernández 1989). Another way of treating this species would be to raise subg. Nervosa to genus level, thus creating a monospecific genus containing $Z$. nervosa only. A parallel case from the Caribbean is met with in Clavija Ruiz \& Pav. (Theophrastaceae), a chiefly South and Central American genus with a single, morphologically and phylogenetically isolated species, C. domingensis Urb. \& Ekman, endemic to Hispaniola (Källersjö and Ståhl 2003; Ståhl 2010), and similar patterns in other neotropical groups should be expected. Nevertheless, Z. nervosa has a combination of characters typical for Zapoteca (polyad structure of pollen and fruit type, as well as overall inflorescence structure) and it seems for now best treated in Zapoteca.

Clade I is strongly supported as monophyletic and as sister to Z. aculeata $+Z$. amazonica and clades II and III (Fig. 2). Clade I contains two terminals of $Z$. filipes and one of $Z$. scutellifera, but $Z$. filipes is not shown to be monophyletic since Zapoteca filipes A is the sister to Z. scutellifera, although this node is not strongly supported (Fig. 2). Both species were placed in subg. Zapoteca by Hernández (1989). Extrafloral glands are only found in these two species and in Z. nervosa (and occasionally in Z. lambertiana). Zapoteca filipes is distinguished by having cylindrical glands between the pinnae and the leaflets placed close to the base of the petioles and Z. scutellifera is distinguished by having scutelliform glands between the pinnae close to the base of the petioles and sometimes also between the distal pairs of leaflets (Hernández 1989). The position of clade I as the closest diverging lineage to $Z$. nervosa could indicate that the occurrence of extrafloral glands is a primitive character in Zapoteca. Both Z. filipes and Z. scutellifera are distributed in Amazonian Brazil, with seemingly overlapping distributions; $Z$. scutellifera also occurs in Bolivia. The results in this study indicate that $Z$. filipes and Z. scutellifera are closely related, but the relationship between them remains unresolved (Fig. 2). Additional material of both species is needed in order to further investigate the phylogenetic relationship of these two species. A new subgenus is possibly needed to accommodate the species of clade I in order to retain subg. Zapoteca (with some adjustments), subg. Aculeata and subg. Amazonica. One possibility is to assign clade II and III to subg. Zapoteca and describe a new subgenus to accommodate clade I.

Zapoteca aculeata is strongly supported as sister to a clade consisting of Z. amazonica + clades II and III and as monophyletic based on two collections (Fig. 2). The present results show that $Z$. aculeata diverged from the main line of descent earlier than $Z$. amazonica and the taxa found in clades II + III, i.e., the taxa placed in subg. Zapoteca (except for Z. filipes and Z. scutellifera of clade I), subg. Amazonica and subg. Ravenia (Table 1) (Hernández 1989, 1990, 2015; Hernández and Hanan-Alipi 1998; Levin and Moran 1989), and thus support a placement of this species in a separate monospecific subgenus, subg. Aculeata (Hernández 1989). Zapoteca aculeata is distinguished from the other species of Zapoteca by having spinescent stipules. It is distributed in the Ecuadorian Andes (Hernández 1989) and appears to be the species of Zapoteca growing at the highest elevations (up to $2800 \mathrm{~m}$ according to Tropicos.org 2018).

The results of this study show Zapoteca amazonica strongly supported as sister to clades II + III (Fig. 2). Hernández (1989) placed Zapoteca amazonica in subg. Amazonica together with Z. microcephala (not included in this study). He considered these two species to represent a distinct evolutionary line within Zapoteca since they were distinguished from all other species of Zapoteca by having one pair of pinnae with few, large, chartaceous to coriaceous leaflets and flower heads arranged in long, simple or compound pseudopanicles. Whereas $Z$. amazonica is known from Amazonian Peru and adjacent Ecuador, $Z$. microcephala is confined to the Magdalena valley in central Colombia. The position of Z. amazonica in this study indicates that this species diverged from the main line of descent earlier than the species found in clade II + III, thus agreeing with the view of Hernández (1989) that $Z$. amazonica (and Z. microcephala) separated early from the other species of Zapoteca. Whether or not Z. microcephala 
is the closest relative to $Z$. amazonica is yet to be tested. One additional species, $Z$. quichoi, endemic to southern Tabasco in Mexico, was included in subg. Amazonica by Hernández and Hanan-Alipi (1998). They considered $Z$. quichoi to be more closely related to the species of subg. Amazonica than to the other Mexican species of Zapoteca, based on morphological features such as leaves with one pair of pinnae with few, large leaflets and inflorescence characters. However, based on the results in this study $Z$. amazonica and $Z$. quichoi are not closely related and $Z$. quichoi is shown to be more closely related to the taxa in subclade X (Fig. 2). Since the relationships within subclade $\mathrm{X}$ are for the most part poorly resolved, the phylogenetic position of $Z$. quichoi needs further study. Also, the inclusion of $Z$. microcephala is needed in order to confirm that $Z$. quichoi is not closely related to any species of subg. Amazonica.

Clade II, including the two subspecies of Zapoteca caracasana, is strongly supported as sister to clade III and shown to be monophyletic (Fig. 2). Furthermore, Z. caracasana subsp. weberbaueri (Harms.) H.M.Hern. is strongly supported as monophyletic based on two specimens, and as sister to subsp. caracasana.

\section{Phylogenetic relationships within clade III}

Clade III is strongly supported as monophyletic (Fig. 2) and contains most of the species of Zapoteca included in this study. Relationships within this clade are generally poorly resolved, but there are some strongly supported nodes.

In subclade X, Zapoteca formosa subsp. gracilis and Z. portoricensis subsp. portoricensis are both shown to be strongly supported as monophyletic, and moderately supported as sisters (Fig. 2). According to Hernández (1989) collections of $Z$. formosa subsp. gracilis from the Bahamas can be confused with Z. portoricensis subsp. portoricensis, but can be distinguished from the latter in having smaller and narrower stipules and thicker leaflets. Two of the collections of $Z$. formosa subsp. gracilis $(\mathrm{A}+\mathrm{C})$ in this study are from the Bahamas, the third (B) was collected in Cuba, whereas the two specimens of Z. portoricensis subsp. portoricensis were collected in Hispaniola. The placement of the three collections of $Z$. formosa subsp. gracilis confirms that they represent the same taxon (Fig. 2). The positions of Z. formosa subsp. gracilis and Z. portoricensis subsp. portoricensis, although only moderately supported, suggest a relationship between these two taxa (Fig. 2). It is possible that $Z$. formosa subsp. gracilis should be treated at the specific level and not as a subspecies, especially since $Z$. formosa is shown to be non-monophyletic. Zapoteca portoricensis is also shown to be non-monophyletic in this study and Z. portoricensis subsp. pubicarpa should possibly be treated at the specific level or at least not as a subspecies of
Z. portoricensis. In any case, the status of the subspecific classifications of $Z$. formosa and Z. portoricensis needs to be investigated further. Also, studies including more samples of both Z. formosa subsp. gracilis and Z. portoricensis subsp. portoricensis from more localities are needed in order to investigate their relationship further.

Zapoteca formosa subsp. rosei and Z. formosa subsp. socorrensis, found in subclade $\mathrm{Y}$, are strongly supported as sister taxa (Fig. 2). They together are in turn strongly supported as sister to a group consisting of the remaining taxa in subclade Y. Zapoteca formosa subsp. rosei is a Mexican taxon known from Baja California and distributed south along the pacific slope while Zapoteca formosa subsp. socorrensis is known only from Socorro and Clarión islands, off the west Mexican coast. Hernández (1989) included the island populations in subspecies Z. formosa subsp. rosei. Levin and Moran (1989) considered the island populations to be morphologically distinct and recognized $Z$. formosa subsp. socorrensis, an endemic to the Socorro and Clarión islands. However, they considered these two subspecies to be closely related because of similarity in morphology. One morphological trait distinguishing the two subspecies from each other is filament color, which in subsp. socorrensis is white while it is bicolored (white basally and pink, purple or red distally) in subsp. rosei. Furthermore, subsp. socorrensis has diurnal flowers, otherwise unknown in Zapoteca, but this feature has only been observed in cultivation (Levin and Moran 1989). The results of this study confirm that these subspecies are more closely related to each other than to any other species of Zapoteca (Fig. 2). Whether the collections included represent distinct taxa or variations of the same taxon, and if they should be treated at subspecific or specific level, is yet to be tested with more samples from both subsp. rosei and subsp. socorrensis.

The two specimens of $Z$. tehuana included in this study are found in a position outside subclades $\mathrm{X}$ and $\mathrm{Y}$, and the species is strongly supported as monophyletic (Fig. 2). Zapoteca tehuana was originally placed in subg. Zapoteca by Hernández (1989), but when Z. ravenii was discovered he (Hernández 1990) considered these two species to be more closely related to each other than to the other species of subg. Zapoteca. This conclusion was based on similarities in the leaf morphology, including venation and texture, and Hernández (1990) established a new subgenus, subg. Ravenia, to accommodate the two species. In contradiction to this, based on the results of this study, Z. tehuana and $Z$. ravenii are not closely related. Instead, $Z$. ravenii is a strongly supported as sister to Z. cruzii (Fig. 2).

Zapoteca ravenii is known from montane rain forest in northern Mexico and from the Cayo District in Belize, occurring at altitudes of 400-900 m (Hernández 1990). By contrast, Zapoteca cruzii has a limited distribution in northeastern Guerrero (southwestern Mexico), where it grows in tropical 
deciduous forest at around $1000 \mathrm{~m}$ altitude (Hernández 2015). Furthermore, Z. cruzii has a scandent habit and the ability to produce adventitious roots, an attribute not known in any other taxon of Zapoteca, and these are traits which also clearly distinguish them from $Z$. ravenii. According to the results in this study, these two species are closely related, but further phylogenetic studies should include collections from Belize and additional morphological studies would be instructive.

Zapoteca formosa $\mathrm{B}$ and $Z$. sousae are strongly supported sisters found in clade III (Fig. 2). Zapoteca sousae was described by Hernández and Campos (1994), but its subgeneric placement has not been addressed. Zapoteca sousae is distinguished from other taxa of Zapoteca by its foliaceous stipules with tawny hairs and calyces with uneven teeth. It is known from two widely separated localities in two Mexican states, Oaxaca and Colima. Further phylogenetic and morphological studies of Zapoteca are needed before any subgeneric placement of $Z$. sousae can be made. It would also be interesting to test the monophyly of $Z$. sousae by including collections from both known localities. Furthermore, its relationship to $Z$. formosa in its broad circumscription also needs further study.

\section{The non-monophyletic species Zapoteca formosa}

All subspecies of Zapoteca formosa are found in clade III, but they are not found grouped together, thus rendering this species non-monophyletic. Zapoteca formosa is distributed throughout the Neotropics, with a northern extension to Arizona, USA, occurring from sea level up to $2000 \mathrm{~m}$ altitude (Tropicos.org 2018). Zapoteca formosa is recognized as an erect shrub up to $5 \mathrm{~m}$ tall with leaves lacking extrafloral nectaries and stamens that are white, greenish white, red-purple or bicolored (with filaments that are white basally and pink or red-purple distally) (Hernández 1989). The species is divided into eight subspecies (Hernández 1989, 2015; Levin and Moran 1989), and all except one (Zapoteca formosa subsp. sinaloana H.M.Hern.) are represented in this study. The subspecies are distinguished morphologically primarily based on a variation in leaf and floral characters, but intermediate forms are known (Hernández 1989). The results of this study clearly indicate that the subspecific classification of $Z$. formosa should be revised given that the subspecies of $Z$. formosa occur intermixed with other taxa in clade III. Since many nodes in clade III are poorly supported (Fig. 2), it is impossible to fully evaluate the monophyletic status of $Z$. formosa without more extensive phylogenetic analyses.

\section{The non-monophyletic species in clade III}

In clade III, several species are shown to be non-monophyletic. Two collections of Zapoteca tetragona are found in subclade $\mathrm{X}$, but the species is not supported as monophyletic (Fig. 2).
Zapoteca portoricensis is shown to be non-monophyletic, subsp. portoricensis being found in subclade $\mathrm{X}$ and subsp. pubicarpa in a position outside subclade X (Fig. 2). Since subsp. portoricensis (discussed above) and subsp. pubicarpa are not closely related, these two taxa might not even represent the same species. The third subspecies of $Z$. portoricensis, subsp. flavida (Urb.) H.M.Hern., needs to be included in any future phylogenetic analyses in order to test the monophyly of Z. portoricensis further. Two collections of Zapoteca alinae are found in subclade $\mathrm{Y}$ and one collection is found outside of that subclade (Fig. 2), rendering this species non-monophyletic. All three specimens of Z. lambertiana included in this study are found in subclade $\mathrm{Y}$, but they are not found clustered together. No conclusions can be drawn about the monophyly of $Z$. lambertiana since none of the three specimens are found in strongly supported positions; thus, more studies are needed in order to investigate this species further. Hernández (1989) concluded that intermediate forms exist for many taxa in subg. Zapoteca but that hybrids are rare in the genus, although they do occasionally occur. Possible hybrids mentioned by him are between $Z$. tetragona and Z. portoricensis subsp. portoricensis, between Z. media and Z. formosa and between Z. formosa subsp. formosa and subsp. rosei, but we cannot rule out the possibility of hybridization between other taxa of Zapoteca. The occurrence of naturally occurring hybrids could partly explain the non-monophyletic status of some taxa in this study. Another possible explanation is the misidentification of some specimens, both in herbaria and in the field, especially because diagnostic characters do not always exist.

\section{Conclusions}

Zapoteca is a well-defined genus based on morphological characters (Hernández 1986, 1989) and its monophyly is strongly supported in this study based on DNA sequence data (Fig. 2). However, the results of this study show that the classification of subgeneric taxa within Zapoteca needs to be revised and the monophyly of species and subspecies, as well as phylogenetic relationships between taxa, needs further study before any well-supported taxonomic rearrangements can be proposed, including the correct subgeneric placement of $Z$. sousae.

Acknowledgements I thank Rodrigo Duno de Stefano at CICY for supplying DNA material and the reviewers for valuable comments on the manuscript. I also thank Sarina Veldman for comments on an early version of the manuscript, Steve Maldonado Silvestrini, Pedro González Gutiérrez and Gwilym Lewis for giving me permission to use their photos. This study was supported by funds from Stiftelsen Lars Hiertas minne, Knigges resestipendium, Sernanders stipendiestiftelse, T. Tullbergs stipendiestiftelse, Ossian Dahlgrens botaniska stipendiestiftelse, Helge Ax:son Johnsons stiftelse and G. Thelins stipendiestiftelse. 
Funding For this study, and my Ph.D project (Systematics, diversity and historical biogeography of Neotropical synandrous mimosoidsthe Ingeae tribe) funding support came from scholarships. This study was supported by funds from Stiftelsen Lars Hiertas minne, Knigges resestipendium, R. Sernanders stipendiestiftelse, T. Tullbergs stipendiestiftelse, Ossian Dahlgrens botaniska stipendiestiftelse, Helge Ax:son Johnsons stiftelse and G. Thelins stipendiestiftelse.

\section{Compliance with ethical standards}

Conflict of interest The author declares that there is no conflict of interest.
Open Access This article is distributed under the terms of the Creative Commons Attribution 4.0 International License (http://creativeco mmons.org/licenses/by/4.0/), which permits unrestricted use, distribution, and reproduction in any medium, provided you give appropriate credit to the original author(s) and the source, provide a link to the Creative Commons license, and indicate if changes were made.

\section{Appendix}

Taxon names and GenBank accession numbers of DNA sequences (ETS, ITS, $\operatorname{trn} \mathrm{L}-\operatorname{trn} \mathrm{F}$ ) included in this study. Voucher data are given for accessions for which DNA sequences were newly obtained, using the following format: taxon name, country, collector and collection number, herbarium acronym; GenBank accession numbers (ETS, ITS, trnL-trnF)

Calliandra dysantha Benth.; EF638121.1, JX870684.1, JX870813.1 $\bullet$ Calliandra surinamensis Benth.; -, JX870747.1, JX870865.1 $\bullet$ Havar dia mexicana (Rose) Britton \& Rose; KF921655.1, KF933276.1, JX870878.1, $\downarrow$ Havardia pallens (Benth.) Britton \& Rose; KF921656.1, KF921698.1, AF522955.1 Pithecellobium diversifolium Benth.; KF921666.1, JX870768.1, JX870884.1 $\bullet$ Pithecellobium dulce (Roxb.) Benth.; EF638143.1, JX856483.1, KC479268.1, Senegalia senegal (L.) Britton; EF638152.1, HQ605075.1, AF522976.1 farnesiana (L.) Wight \& Arn.; EF638128.1, AF360728.1, AY574119.1 Viguieranthus ambongensis (R.Vig.) Villiers; KR997873.1, JX870773.1, JX870890.1 Viguieranthus subauriculatus Villiers; KR997876.1, JX870778.1, - Zapoteca aculeata (Spruce ex Benth.) H.M.Hern. (A) Ecuador, Delinks 332 (NY); MK622329*, MK638924*, MK622373* (B) Ecuador, Rose 22365 (NY); MK622330*, -, MK622363* Zapoteca amazonica (Benth.) H.M.Hern., Peru, Mexia 8295 (S); MK622344*, MK638946*, MK622377* Zapoteca alinae H.M.Hern. (A) Mexico, Pascual 1492 (NY); MK622336*, MK638925*, MK622368* (B) Mexico, Gomez 91-7-7 (NY); -, MK638926*, (C) -, JX870779.1, JX870893.1 \ Zapoteca balsasensis H.M.Hern., Mexico, Contreras \& Thomas 1735 (NY); -, MK638928*, - Zapoteca caracasasa (Jacq.) H.M.Hern. subsp. caracasana, Hispaniola, Ekman 16527 (S); MK622335*, MK638949*, MK622370* Zapoteca caracasasa subsp. weberbaueri (Harms.) H.M.Hern. (A) Ecuador, Asplund 15982 (S); MK622345*, MK638947*, MK622374* (B) Ecuador, Asplund 15503 (S); MK622333*, MK638948*, MK622376* Zapoteca costaricensis (Britton \& Rose) H.M.Hern., Costa Rica, Morales \& Hammel 9051 (MO); -, MK638961*, - Zapoteca cruzii H.M.Hern., Mexico, Gual 272 (MEXU); MK622328*, MK63896*2, MK622375* Zapoteca filipes (Benth.) H.M.Hern.; (A) Brazil, Teixeira 476 (NY); -, MK638927*, MK622367* (B) -, JX870780.1, JX870896.1 Zapoteca formosa (Kunth.) H.M.Hern. subsp. not assigned; (A) Novara \& Bruno 8865 (S); -, MK638950*, MK622356* (B) -, JX870781.1, JX870897.1 \apoteca formosa subsp. formosa, (Kunth.) H.M.Hern. (A) Mexico, McVaugh 20327 (NY); -, MK638929*, (B) Mexico, McVaugh 19857 (NY); -, MK638930*, - Zapoteca formosa subsp. gracilis (Griseb.) H.M.Hern. (A) Bahamas, Howard 10021 (S); MK622346*, MK638951*, MK622362* (B) Cuba, Ekman 8198 (S); MK622347*, MK638952*, MK622359* (C) Bahamas, Webster, Samule \& Williams 10511A (S); MK622348*, MK638953*, MK622372* Zapoteca formosa subsp. mollicula (J.F.Macbr.) H.M.Hern., Mexico, Hughes 1804 (NY); MK622337*, MK638931*, MK622362* Zapoteca formosa subsp. rosei (Wiggins) H.M.Hern., Mexico, Mexia 8731 (NY); MK622353*, MK638932*, - Zapoteca formosa subsp. salvadorensis (Britton \& Rose) H.M.Hern. (A) Guatemala, G.J. \& M.E. Breckon 2118 (NY); MK622352*, MK638933*, - (B) Guatemala, Williams \& al. 22456 (NY); MK622338*, MK638934*, MK622355* Zapoteca formosa subsp. schottii (Torr. ex S.Watson) H.M.Hern. (A) US/Arizona, Parker 5861 (NY); -, MK638935*, - (B) US/Arizona, Kearney \& Peebles 14960 (NY); MK622339*, MK638936*, MK622357* (C) Semillas cultivadas XDL89-0405D (CICY) MK638923*, -, MK622379* Zapoteca formosa subsp. socorrensis (I.M.Johnst.) G.A.Levin, H.M.Hern. \& Moran, Mexico, Moran 25546 (NY); MK622340*, MK638937*, - Zapoteca lambertiana (G.Don) H.M.Hern.; (A) Mexico, Breedlove 36732 (NY); MK622331*, MK638938*, MK622360* (B) Mexico, Ton 3042 (NY); MK622332*, MK638939*, - (C) -, JX870782.1, JX870894.1 $\bullet$ Zapoteca media (M. Martens \& Galeotti) H.M.Hern.; (A) Mexico, Moore Jr. 3986 (NY); MK622341*, MK638940*, MK622365* (B) Mexico, Johnston 12043 (NY); MK622351*, MK638941*, MK622366* Zapoteca mollis (Standl.) H.M.Hern., Costa Rica, Rodriguez 2420 (NY); MK622342*, MK638942*, - Zapoteca nervosa (Urb.) H.M.Hern. (A) Hispaniola, Ekman 8959 (S); MK622349*, MK638954*, - (B) Hispaniola, Ekman 15423 (S); -, MK638955*, MK622358* Zapoteca portoricensis (Jacq.) H.M.Hern. subsp. portoricensis; (A) Hispaniola, Ekman 10924 (S); MK622350*, MK638956*, MK622371* (B) Hispaniola, Ekman 13376 (S); MK622334*, MK638957*, - Z Zapoteca portoricensis subsp. pubicarpa H.M.Hern., Mexico, Purpus 2668 (NY); -, MK638943*, - $\downarrow$ Zapoteca ravenii H.M.Hern., Mexico, Martinez 23967 (NY); MK622343*, MK638944*, MK622369* Zapoteca scutellifera (Benth.) H.M.Hern., Brazil, Amaral 1231 (NY); -, MK638945*, - Zapoteca sousae H.M.Hern. \& A.Campos; -, JX870783.1, JX870898.1 Zapoteca tehuana H.M.Hern. (A) Mexico, A.Campos 4108 (MEXU) MK622326*, MK638963*, MK622378* (B) Mexico, Torres Colín 8934 (MEXU); -, MK638959*, MK622354* Zapoteca tetragona (Willd.) H.M.Hern.; (A) Colombia, Cuatrecasas 22400 (S); -, MK638958*, - (B) -, JX870784.1, JX870899.1 Zapoteca quichoi H.M.Hern \& A.M.Hanan, Mexico, Calónico 21109 (MEXU); MK622327*, MK638960*, MK622364*

- missing data; * newly generated sequence 


\section{References}

Ariati SR, Murphy DJ, Udovicic F, Ladiges PY (2006) Molecular phylogeny of three groups of acacias (Acacia subgenus Phyllodineae) in arid Australia based on the internal and external transcribed spacer regions of nrDNA. Syst Biodivers 4:417-426. https://doi. org/10.1017/S1477200006001952

Baldwin BG, Markos S (1998) Phylogenetic utility of the external transcribed spacer (ETS) of 18S-26S rDNA: Congruence of ETS and ITS trees of Calycadenia (Compositae). Molec Phylogen Evol 10:449-463

Brown GK, Murphy DJ, Miller JT, Ladiges PY (2008) Acacia s.s. and its relationship among tropical legume tribe Ingeae (Leguminosae: Mimosoideae). Syst Bot 33:739-751. https://doi. org/10.1600/036364408786500136

Edgar RC (2004) MUSCLE: multiple sequence alignment with high accuracy and high throughput. Nucl Acids Res 32:1792-1797

Guinet P, Hernández HM (1989) Pollen characters in the genera Zapoteca and Calliandra (Leguminosae, Mimosoideae) and their systematics and phylogenetic relevance. Pollen Spores 31:5-22

Hernández HM (1986) Zapoteca: a new genus of neotropical Mimosoideae. Ann Missouri Bot Gard 73:755-763

Hernández HM (1989) Systematics of Zapoteca (Leguminosae). Ann Missouri Bot Gard 76:781-862

Hernández HM (1990) A new subgenus and a new species of Zapoteca (Leguminosae). Syst Bot 15:226-230

Hernández HM (2015) New taxa of Zapoteca (Leguminosae, Mimosoideae) from Mexico. Phytotaxa 239:233-241

Hernández HM, Campos A (1994) A new species of Zapoteca (Leguminosae, Mimosoideae) from Mexico. Novon 4:32-34

Hernández HM, Hanan-Alipi AM (1998) Zapoteca quichoi (Leguminosae, Mimosoideae), a new species from southeastern Mexico. Brittonia 50:211-213. https://doi.org/10.2307/2807853

Källersjö M, Ståhl B (2003) Phylogeny of Theophrastaceae (Ericales s.l.). Int J Pl Sci 164:579-591. https://doi.org/10.1086/375317

Kearse M, Moir R, Wilson A, Stones-Havas S, Cheung M, Sturrock S, Buxton S, Cooper A, Markowitz S, Duran C, Thierer T, Ashton B, Mentjies P, Drummond A (2012) Geneious basic: an integrated and extendable desktop software platform for the organization and analysis of sequence data. Bioinformatics 28:1647-1649

Kyalangalilwa B, Boatwright JS, Daru BH, Maurin O, van der Bank M (2013) Phylogenetic position and revised classification of Acacia s.l. (Fabaceae: Mimosoideae) in Africa, including new combinations in Vachellia and Senegalia. Bot J Linn Soc 172:500-523. https://doi.org/10.1111/boj.12047

Larsson A (2010) Abioscripts. Available at: http://ormbunkar.se/phylo geny/abioscripts/

Larsson A (2014) AliView: a fast and lightweight alignment viewer and editor for large data sets. Bioinformatics 30:3276-3278

Levin GA, Moran R (1989) The vascular flora of Isla Socorro, Mexico. Mem San Diego Soc Nat Hist 16:37

Nylander JAA (2004) MrAIC.pl. Program distributed by the author. Evolutionary Biology Centre, Uppsala University. Available at: https://github.com/nylander/MrAIC

Popp M, Oxelman M (2001) Inferring the history of the polyploid Silene aegae (Caryophyllaceae) using plastid and homoeologous nuclear DNA sequences. Molec Phylogen Evol 20:474-481

Rambaut A (2006-2016) FigTree, version 1.4.3. Institute of Evolutionary Biology, University of Edinburgh. Available at: http://tree.bio. ed.ac.uk/software/figtree/

Rambaut A, Suchard M, Drummond A (2014) Tracer, version 1.6. Institute of Evolutionary Biology, University of Edinburgh. Available at: http://tree.bio.ed.ac.uk/software/tracer/

Ronquist F, Huelsenbeck JP, Teslenko M (2011) Draft MrBayes version 3.2 Manual. Tutorials and Model Summaries. http://mrbayes.sourc eforge.net/download.php

Souza ER, Lewis GP, Forest F, Schnadelbach AS, van der Berg C, Paganucci de Queiros L (2013) Phylogeny of Calliandra (Leguminosae: Mimosoideae) based on nuclear and plastid molecular markers. Taxon 62:1200-1219

Ståhl B (2010) Theophrastaceae. Fl Neotrop. Monogr 105:1-161

Taberlet P, Gielly L, Patou G, Bouvet J (1991) Universal primers for amplification of three non-coding regions of chloroplast DNA. Pl Molec Biol 17:1105-1109. https://doi.org/10.1007/BF00037152

Tropicos.org (2018) Tropicos: botanical information system. Missouri Botanical Garden, Saint Louis. Available at: http://www.tropicos. org/. Accessed 17 Apr 2018

Publisher's Note Springer Nature remains neutral with regard to jurisdictional claims in published maps and institutional affiliations. 